\title{
Sosialisasi dan Edukasi Penilaian Mandiri terhadap Risiko Penularan COVID-19 melalui InaRISK Personal
}

\author{
Sufiyanto Sufiyanto ${ }^{1}$, Sari Yuniarti ${ }^{2}$ Djoko Andrijono $^{1}$ \\ ${ }^{1}$ Departemen Teknik Mesin Fakultas Teknik, ${ }^{2}$ Departemen Diploma D-III Perbankan dan Keuangan \\ Fakultas Ekonomi dan Bisnis, Universitas Merdeka Malang. \\ Jl. Terusan Raya Dieng No.62-64 Malang, 65146, Indonesia
}

\section{ARTICLE INFO:}

Received: 2020-08-04 Revised: $2020-9-10$ Accepted: 2020-10-08

Keywords:

COVID-19; Education; Personal InaRISK; Protocols; Self-assessment

\section{ABSTRACT}

The implementation of the COVID-19 protocol was carried out as part of an effort to revive the economy that slumped due to the COVID-19 pandemic. Public awareness in implementing COVID-19 protocols is important in the New Normal life rules. This service activity helps the community to carry out an independent assessment of the risk of spreading and transmitting the COVID-19 virus. Also, it provides education and raises awareness to the public regarding health protocols. This method uses the InaRISK Personal application developed by the National Disaster Management Agency or Badan Nasional Penanggulangan Bencana (BNPB). The community as respondents is helped to obtain an independent assessment by filling in the answers to the questionnaire into the InaRISK Personal application. The results showed that $57.2 \%$ had low-risk status, $40.3 \%$ medium risk, and $2.5 \%$ high-risk status. Some of the behaviors that have the potential to increase the risk of contracting the COVID19 virus are $89 \%$ of respondents touching money and $86.3 \%$ traveling for the risk of contracting outside the home, $55.5 \%$ of respondents do not provide hand sanitizers at home for the risk of contracting at home, $46,8 \%$ of respondents did not drink vitamins $C$ and $E$ and lack of sleep for risks related to immunity. The conclusion is that the public still needs to increase awareness in carrying out health protocols to reduce the risk of spreading and transmitting the COVID-19 virus.

(c) 2020 Published by University of Merdeka Malang. This is an open access article distributed under the CC BY-SA 4.0 license

(https://creativecommons.org/licenses/by-sa/4.0/)

How to cite: Sufiyanto, S., Yuniarti, S., \& Andrijono, D. (2020). Sosialisasi dan Edukasi Penilaian Mandiri terhadap Risiko Penularan COVID-19 melalui InaRISK Personal. Abdimas: Jurnal Pengabdian Masyarakat Universitas Merdeka Malang, 5(3), 209-219. https://doi.org/10.26905/abdimas.v5i3.5004

\section{PENDAHULUAN}

Pandemi COVID-19 telah menjadi suatu ancaman yang nyata bagi seluruh masyarakat dunia tak terkecuali Indonesia (Yunus \& Rezki, 2020). Dampak munculnya pandemi ini telah melumpuhkan sebagian besar sektor perekonomian utamanya di negara-negara berkembang. Kebijakan pemerintah sebagai upaya pencegahan penularan dan penyebaran virus COVID-19 telah berdampak secara ekonomi bagi masyarakat 
ABDIMAS: Jurnal Pengabdian Masyarakat Universitas Merdeka Malang

Volume 5, No 3, November 2020: 209-219

(Berawi, 2020; Irawan et al., 2020). Penerapan program Pembatasan Sosial Berskala Besar (PSBB) dan lock down (Yunus \& Rezki, 2020) (WHO, 2020) menyebabkan dampak ekonomi yang luar biasa bagi sebagian besar negara-negara berkembang. Hal tersebut mengakibatkan krisis ekonomi dan tingginya tingkat Pemutusan Hubungan Kerja (PHK) di sektor industri karena perusahaan tersebut tidak mampu menggaji karyawannya yang dirumahkan selama penerapan PSBB.

Meskipun kebijakan PSBB dan lock down telah diterapkan oleh pemerintah sebagai upaya pencegahan Covid-19, namun secara nyata angka penularan dan kematian yang terjadi menjadi hal yang sangat mengkhawatirkan dan menjadi ancaman yang serius bagi masyarakat (WHO, 2020). Dalam hal ini ada suatu kondisi yang dilematis dimana penerapan kebijakan PSBB dan dampak ekonomi menjadi dua hal yang saling bertolak belakang. Penerapan kebijakan PSBB dengan ketat diharapkan mampu menekan tingkat penularan dan kematian, namun di sisi yang lain akan menjadi beban yang besar di sektor perekonomian. Apabila tetap mempertahankan aktivitas perekonomian, maka risiko yang terjadi adalah peningkatan risiko penularan dan kematian akibat Covid-19.

Dengan kondisi tersebut, maka munculah suatu konsep baru yang diterapkan masyarakat dalam masa pandemi COVID-19 (Satria et al., 2020). Konsep tatanan baru ini disebut dengan New Normal. New Normal adalah suatu konsep dimana masyarakat menjalankan kehidupan secara normal dengan menggunakan tatanan atau aturan baru sebagai bentuk adaptasi terhadap kondisi lingkungan yang ada sekarang. Salah satu bentuk implementasi dari konsep New Normal adalah aturan tentang protokol kesehatan (KMK No.HK.01.07-MENKES-413-2020) yang harus diterapkan oleh masyarakat dalam menjalani kehidupan normal dalam kondisi pandemi COVID-19 (Irawan et al., 2020; Prayitno et al., 2020). Protokol kesehatan ini sebagai bentuk proteksi diri untuk menjalani kehidupan normal untuk mencegah penularan dan penyebaran virus COVID-19 yang diharapkan dapat menekan risiko penularan dan kematian akibat virus COVID-19 (Majid, 2020).

Beberapa ketentuan yang menjadi bagian dalam protokol kesehatan antara lain: penerapan pola hidup sehat, penggunaan alat pelindung diri, dan pembatasan interaksi fisik (WHO, 2020). Secara teknis, penerapan aturan protokol kesehatan bagi masyarakat merupakan upaya yang paling rasional dan efektif untuk diterapkan. Namun, terdapat beberapa kendala atau hambatan di dalam penerapan aturan protokol kesehatan di masyarakat. Hal yang paling mendasar sebagai faktor penghambat adalah tingkat kesadaran dan pemahaman masyarakat terhadap penerapan aturan protokol kesehatan tersebut. Masyarakat belum secara keseluruhan memiliki tingkat kesadaran dan pemahaman dalam menerapkan aturan protokol kesehatan sebagai bagian bentuk budaya baru yang harus diterima atau dilakukan oleh masyarakat dalam tatanan kehidupan New Normal.

Untuk meningkatkan kesadaran dan pemahaman masyarakat beberapa cara sosialisasi dilakukan termasuk melalui media sosial (Audry et al., 2020; Sampurno et al., 2020) dan peran pemerintah (Zahrotunnimah, 2020). Pemerintah berupaya memberikan sebuah langkah sosialisasi dan edukasi kepada masyarakat melalui metode penilaian mandiri terhadap risiko penularan COVID-19 (https://covid19.go.id). Metode ini diimplementasikan dalam bentuk aplikasi InaRISK yang dikembangkan oleh Badan Nasional Penganggulangan Bencana (BNPB) (BNPB, 2020). Melalui aplikasi InaRISK, pemerintah dapat melakukan pemantauan terhadap indeks risiko bencana secara umum termasuk COVID-19. Hal ini penting bagi peme- 


\section{Sosialisasi dan Edukasi Penilaian Mandiri terhadap Risiko Penularan COVID-19 melalui InaRISK Personal}

Sufiyanto Sufiyanto, Sari Yuniarti, Djoko Andrijono

rintah sebagai dasar pertimbangan pengambilan keputusan dalam menyusun strategi, kebijakan dan program untuk menanggulangi risiko bencana secara nasional maupun regional.

Aplikasi InaRISK dapat digunakan oleh masyarakat secara luas, dimana peran masyarakat sebagai responden dalam pendataan dengan cara mengisi kuisioner yang diberikan di dalam apikasi tersebut. Adapun manfaat bagi masyarakat melalui penggunaan aplikasi InaRISK ini adalah sebagai sarana edukasi dalam memahami tingkat risiko bencana dan meningkatkan kesiapsiagaan dalam menghadapi bencana. Aplikasi InaRISK khususnya InaRISK Personal penting dimiliki oleh masyarakat agar mampu mempersiapkan diri dan keluarga dalam menghadapi situasi ancaman bencana termasuk COVID-19 pada saat ini.

Dalam rangka membantu program pemerintah khususnya BNPB dalam penanganan dan pencegahan COVID-19, peran serta institusi pendidikan diharapkan melalui kegiatan pengabdian masyarakat. Program pengabdian masyarakat yang dilakukan bertujuan untuk membantu dalam mensosialisasikan dan mengedukasi masyarakat tentang aturan protokol kesehatan yang diterapkan sebagai upaya pencegahan penularan dan penyebaran virus COVID-19. Bentuk program pengabdian masyarakat yang dilakukan adalah membantu masyarakat dalam melakukan penilaian mandiri melalui aplikasi InaRISK Personal. Dengan penilaian mandiri tersebut, masyarakat dapat mengetahui tingkat risiko dan perilaku dirinya dalam kondisi pandemi COVID-19 pada saat ini (https://covid19.go.id). Selain itu, hasil pendataan melalui InaRISK Personal dapat digunakan oleh BNPB untuk melihat kondisi dan tingkat penyebaran kasus COVID-19 di masyarakat yang menjadi responden (BNPB, 2020).

Program pengabdian masyarakat yang dilakukan melalui pendataan masyarakat dengan aplikasi InaRISK Personal ini berorientasi pada beberapa permasalahan yang terjadi di masyarakat, antara lain: (1) Perlunya pemahaman bagi masyarakat terhadap pola penularan dan penyebaran virus COVID-19; (2) Perlunya penilaian mandiri bagi masyarakat terhadap tingkat risiko terhadap virus COVID-19 dan rekomendasi pencegahan penularan dan penyebaran virus COVID-19; (3) Adanya kebutuhan untuk melakukan pemetaan status risiko masyarakat terhadap ancaman penularan dan penyebaran virus COVID19 di suatu wilayah.

\section{METODE}

Metode yang dilakukan untuk menyelesaikan permasalahan dalam kegiatan pengabdian masyarakat ini adalah sosialisasi kepada masyarakat tentang pola penularan dan penyebaran virus COVID-19 dan pendataan responden dengan aplikasi InaRISK Personal untuk memperoleh penilaian mandiri terhadap tingkat risiko terhadap virus COVID-19 dan rekomendasi pencegahan penularan dan penyebaran virus COVID-19.

\section{Skedul Pelaksanaan Kegiatan}

Pelaksanaan kegiatan pengabdian masyarakat ini memerlukan waktu 1 bulan yang dilaksanakan mulai 1 s/d 31 Agustus 2020. Kegiatan ini melibatkan 20 mahasiswa yang terbagi dalam 3 tim yaitu tim pendata, tim sosialisasi dan tim pengolah data. Adapun skedul pelaksanaan kegiatan dapat dilihat pada Tabel 1. 
ABDIMAS: Jurnal Pengabdian Masyarakat Universitas Merdeka Malang

Volume 5, No 3, November 2020: 209-219

Tabel 1. Skedul pelaksanaan kegiatan

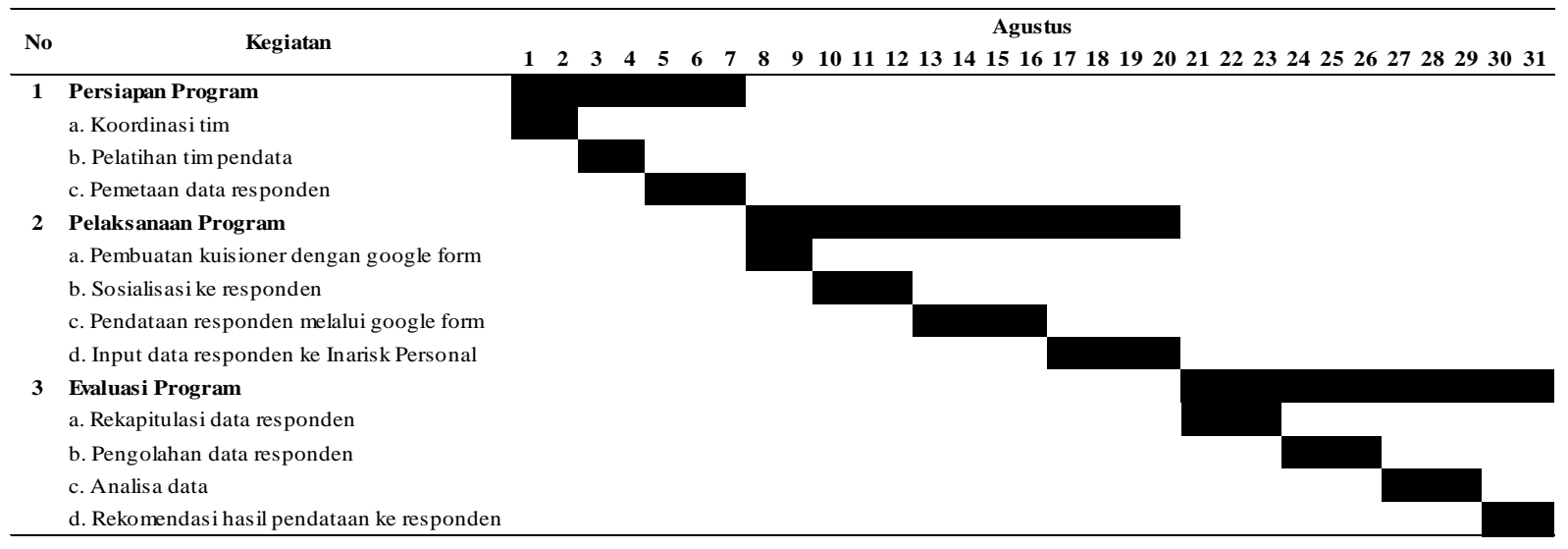

\section{Uraian/Tahapan Pelaksanaan Kegiatan}

Secara garis besar, tahapan pelaksanaan kegiatan pengabdian masyarakat ini ada 3 fase yaitu persiapan, pelaksanaan dan evaluasi program. Adapun uraian kegiatan pada setiap tahapan/fase sebagai berikut.

\section{Persiapan program}

Dalam tahapan persiapan program, tim pelaksana mengawali dengan melakukan koordinasi awal untuk merencanakan dan pembagian tugas sesuai tim yang sudah ditetapkan. Setiap tim membuat pemetaan/inventarisasi tugas dan kebutuhan yang diperlukan saat pelaksanaan kegiatan. Untuk tim pendata diberikan pelatihan tentang aplikasi InaRISK Personal yang akan digunakan untuk memasukkan data dari responden. Selain itu, juga mempelajari pertanyaan kuisioner yang ada di dalam aplikasi tersebut untuk kemudian menjadi bahan/materi dalam pembuatan google form kuisioner.

Setelah itu, tim sosialisasi melakukan pemetaan calon responden yang akan didata menggunakan aplikasi InaRISK Personal. Teknis pemetaan calon responden menggunakan pendekatan hubungan atau relasi dengan mahasiswa yang menjadi anggota dalam tim pelaksana ini. Masing-masing mahasiswa merencanakan 20 calon responden, sehingga nanti akan diperoleh 400 calon responden. Syarat tambahan calon responden yang direncanakan adalah responden yang berdomisili sesuai dengan alamat di Kartu Tanda Penduduk (KTP). Informasi data yang diperlukan dari responden untuk melengkapi isian di aplikasi InaRISK Personal antara lain: alamat lengkap, pekerjaan, umur, alamat email, dan jenis kelamin.
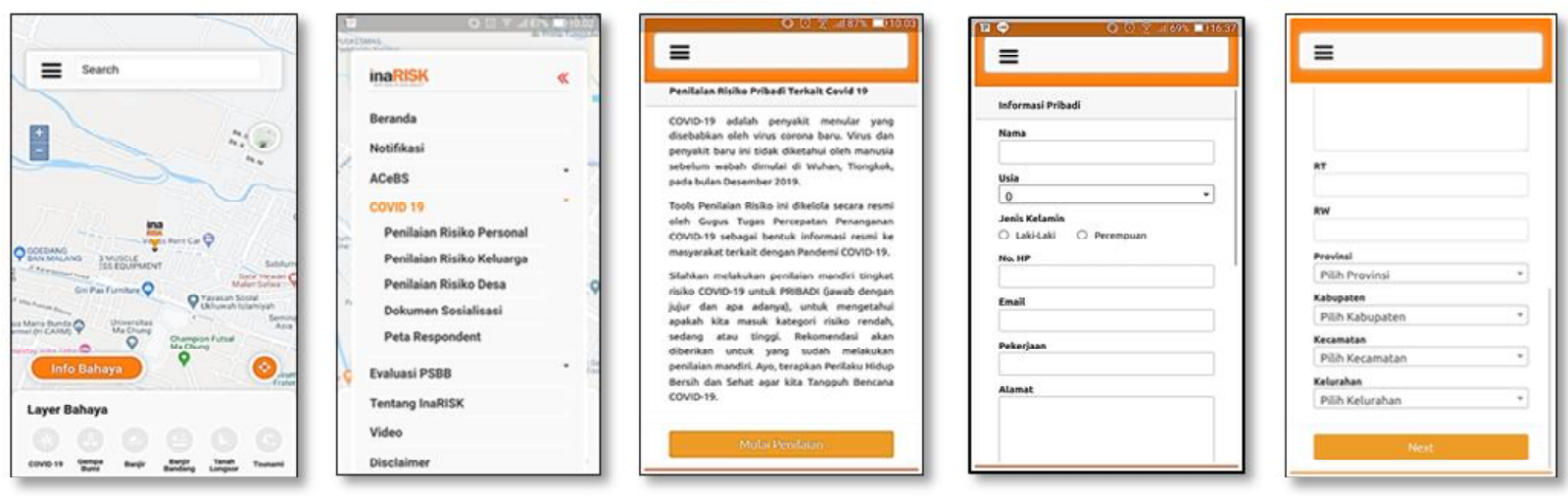

Gambar 1. Tampilan aplikasi InaRISK Personal di android 


\section{Pelaksanaan program}

Inventaris pertanyaan dan data responden yang telah dilakukan pada tahap persiapan digunakan untuk membuat kuisioner menggunakan Google Form (Gambar 3). Hal ini dilakukan karena dalam pendataan dengan aplikasi InaRISK Personal, tim pendata tidak boleh melakukan interaksi fisik secara langsung dengan responden. Semua komunikasi dengan responden dilakukan melalui media chatting di WhatsApp (WA). Disini pentingnya pemetaan calon responden yang memiliki relasi atau kedekatan hubungan dengan mahasiswa anggota tim pelaksana.
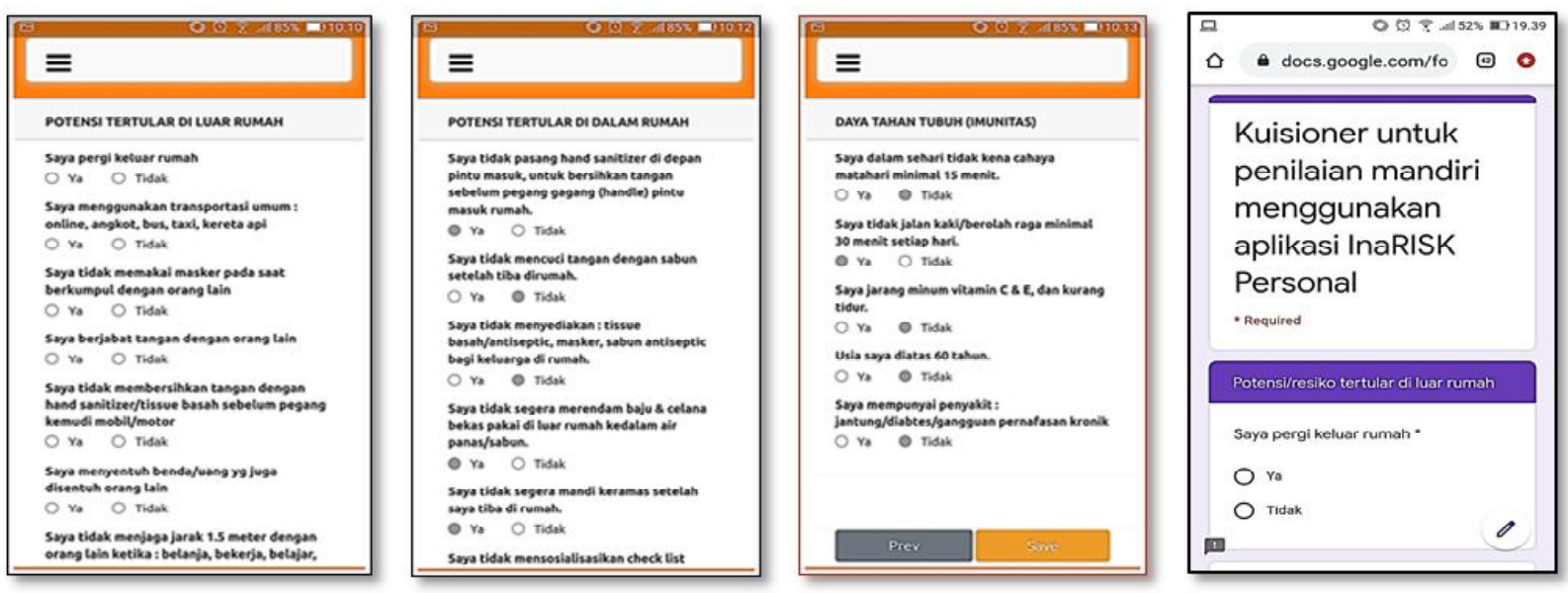

Gambar 2. Pertanyaan kuisioner di aplikasi InaRISK Personal Gambar 3. Tampilan Google Form kuisioner

Setelah kuisioner dengan Google Form selesai dibuat, maka tugas tim sosialisasi adalah menghubungi secara personal calon responden untuk menginformasikan dan mensosialisasikan tentang InaRISK Personal. Selain itu, responden harus dipastikan terlebih dahulu apakah responden sudah pernah mendata sendiri atau didata menggunakan aplikasi InaRISK Personal. Responden yang akan didata adalah masyarakat yang belum pernah terdata di InaRISK Personal. Langkah selanjutnya, tim sosialisasi mengirimkan link Google Form (https://forms.gle/oPfDLp6p5mh9DjPb6) dan meminta responden mengisi kuisioner di dalamnya. Tema pertanyaan kuisioner di InaRISK Personal meliputi: (1) risiko tertular di luar rumah; (2) risiko tertular di dalam rumah; (3) daya tahan/imunitas.

Tim pendata bertugas untuk mendownload respon kuisioner yang sudah diisi oleh responden. Berdasarkan isian respon kuisioner tersebut, data-data tersebut di-input ke aplikasi InaRISK Personal. Setiap responden yang datanya telah selesai di-input akan muncul ID report dan status risikonya. Data status risiko dan ID report yang dihasilkan InaRISK Personal dicatat dalam tabel sebagai bahan untuk melakukan pengolahan data.

\section{Evaluasi program}

Data respon kuesioner di Google Form dan tabel status risiko beserta ID report digunakan untuk melakukan pengolahan data. Hasil pengolahan data tersebut nantinya digunakan untuk memberikan informasi balik kepada responden mengenai status risiko dan rekomendasi yang perlu dilakukan terkait 
ABDIMAS: Jurnal Pengabdian Masyarakat Universitas Merdeka Malang Volume 5, No 3, November 2020: 209-219

hasil penilaian perilakunya. Dari informasi tersebut diharapkan dapat memberikan edukasi dan meningkatkan kesadaran masyarakat dalam penerapan aturan protokol kesehatan guna mencegah penularan dan penyebaran virus COVID-19.

\section{HASIL DAN PEMBAHASAN}

\section{Daerah Asal Responden}

Gambar 4 menampilkan daerah asal responden berdasarkan provinsinya, dimana sebagian besar responden berasal dari provinsi Jatim dan NTT. Hal ini berhubungan dengan hubungan relasi anggota tim pelaksana mahasiswa yang sebagian besar berasal dari kedua provinsi.
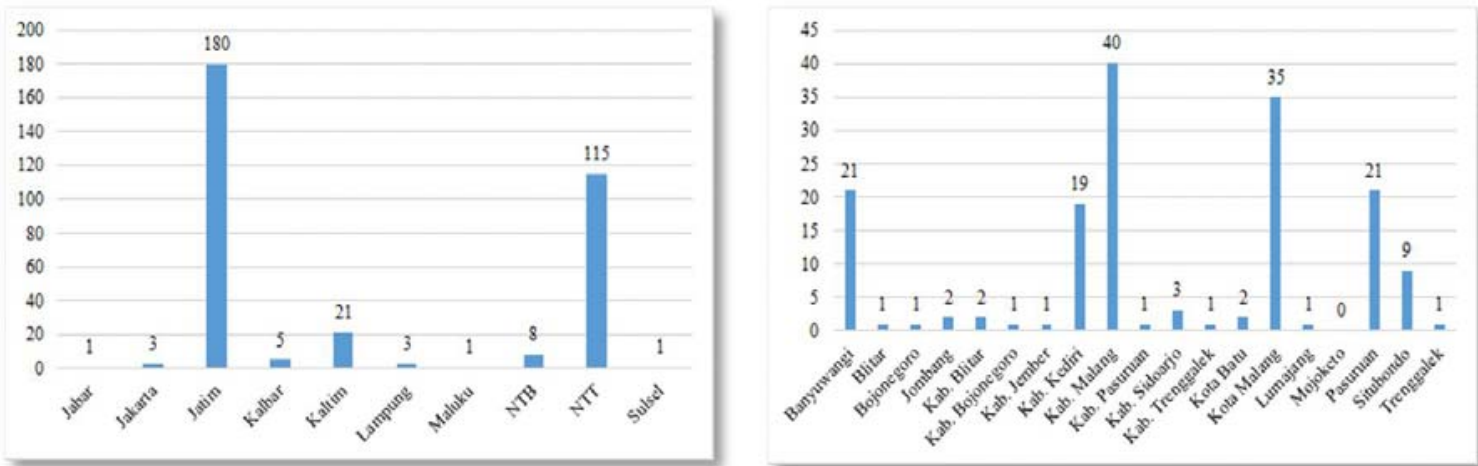

Gambar 5. Sebaran responden berdasar asal kota dan kabupaten di Jatim

Untuk melihat lebih detail, responden yang berasal dari Jatim tersebar di kota dan kabupaten dapat dilihat pada Gambar 5. Terdapat 3 daerah terbanyak mulai Kabupaten Malang, Kota Malang, Banyuwangi dan Pasuruan.
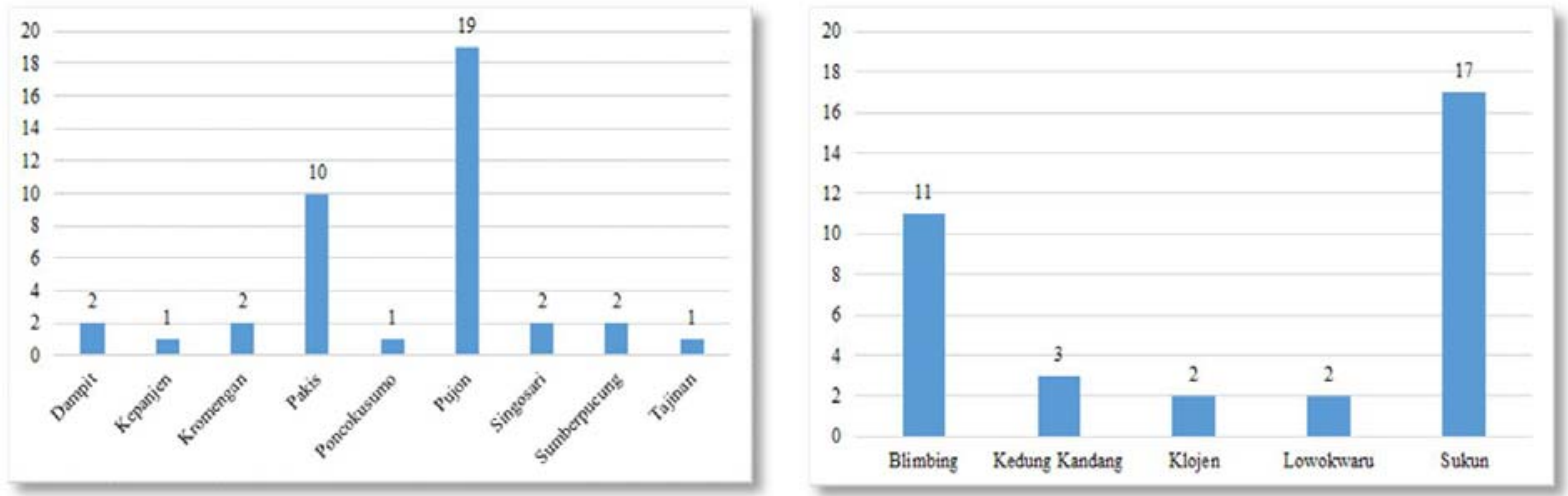

Gambar 6. Sebaran responden di Kabupaten Malang Gambar 7. Sebaran responden di Kota Malang 
Untuk wilayah Kabupaten Malang, responden didominasi dari daerah Kecamatan Pujon dan Pakis berdasarkan Gambar 6. Sedangkan untuk wilayah Kota Malang, sebagian besar responden berasal dari Kecamatan Sukun dan Kecamatan Blimbing (Gambar 7).

\section{Jenis Pekerjaan Responden}

Secara keseluruhan, jenis pekerjaan responden terbanyak adalah mahasiswa, pekerja di perusahaan swasta, pelajar dan wiraswasta.
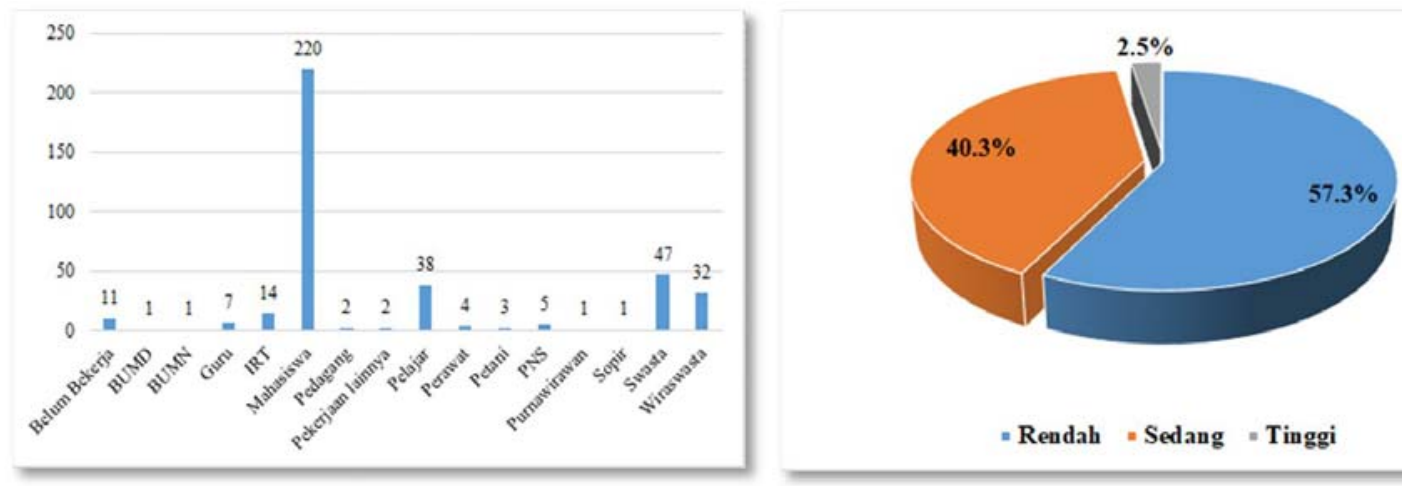

Gambar 8. Jenis pekerjaan responden

Gambar 9. Status risiko responden secara keseluruhan

\section{Status Risiko Responden}

Berdasarkan data kuesioner yang diberikan oleh responden setelah diinput ke aplikasi InaRISK oleh tim pengisi data (Gambar 9), diperoleh hasil 57,3\% responden berstatus risiko rendah, $40,4 \%$ dengan status risiko sedang, dan 2,5\% dengan risiko tinggi. Status risiko ini berdasarkan pola perilaku responden yang dinilai menggunakan aplikasi InaRISK Personal terkait tingkat risiko tertular di luar rumah, risiko tertular di dalam rumah, dan tingkat imunitasnya.
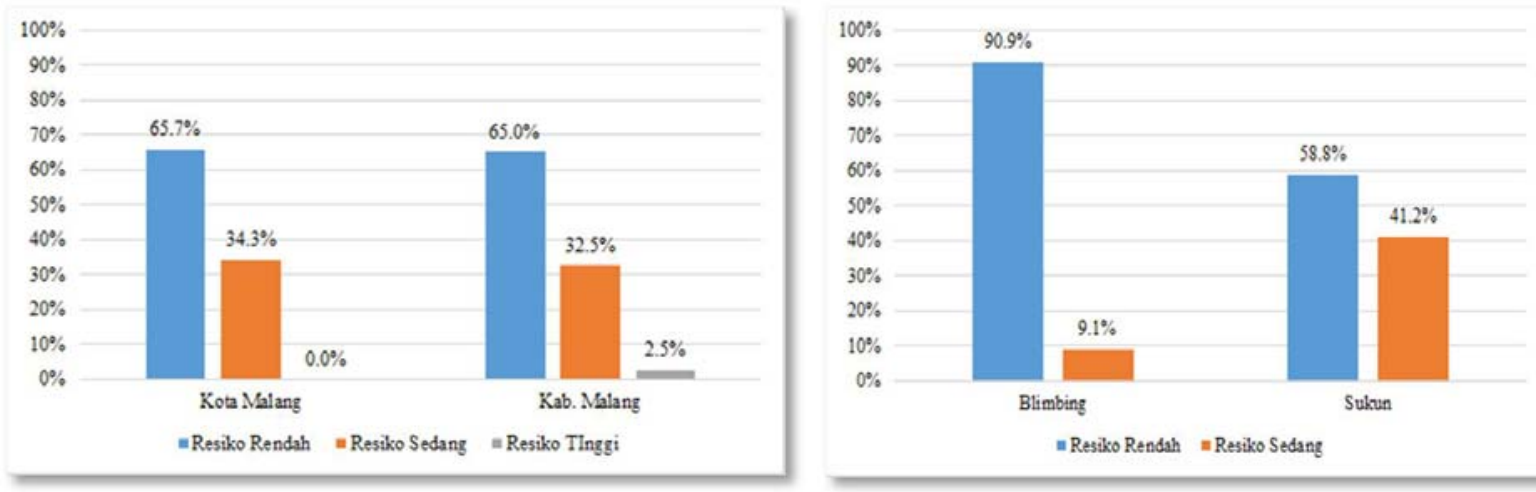

Gambar 10. Status risiko di Kota Malang dan Kabupaten Malang Gambar 11. Status risiko di Kecamatan Blimbing dan Kecamatan Sukun 
ABDIMAS: Jurnal Pengabdian Masyarakat Universitas Merdeka Malang

Volume 5, No 3, November 2020: 209-219

Gambaran status risiko untuk Kota Malang dan Kabupaten Malang dapat dilihat pada Gambar 10. Kedua wilayah ini dibandingkan karena memiliki responden terbanyak untuk Jatim (gambar 5). Tingkat risiko di kedua wilayah kota dan kabupaten hampir menunjukkan kondisi yang sama karena kedua wilayah ini merupakan daerah yang dengan mobilitas dan usia produktif yang tinggi. Hal ini berkontribusi terhadap risiko sedang di atas 30\%, bahkan teridentifikasi 2,5\% dengan risiko tinggi.

Penelusuran lebih detail untuk Kota Malang, sebagian besar responden berasal dari Kecamatan Sukun dan Kecamatan Blimbing. Perbandingan kedua wilayah menunjukkan bahwa Kecamatan Sukun memiliki $41,2 \%$ responden dengan tingkat risiko sedang lebih tinggi dibanding Kecamatan Blimbing yang hanya 9,1\% (Gambar 11). Untuk wilayah Kabupaten Malang, sebagian besar responden berasal dari Kecamatan Pakis dan Kecamatan Pujon dimana tingkat risiko sedang keduanya hampir sama. Sedangkan untuk risiko tinggi hanya terjadi di wilayah Kecamatan Pujon sebesar 5,3\%.

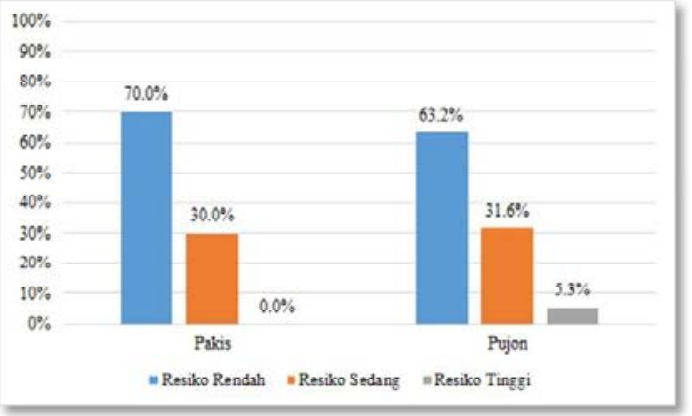

Gambar 12. Status risiko di Kecamatan Pakis dan Kecamatan Pujon

\section{Pola Perilaku Berdasarkan Risiko Tertular Di Luar Rumah}

Untuk menganalisa kondisi status risiko dilakukan melalui penilaian pola perilaku responden berdasarkan tiga hal yaitu: risiko tertular di luar rumah, risiko tertular di dalam rumah, dan daya tahan atau imunitas responden. Gambar 13 menunjukkan perilaku responden berdasar risiko tertular di luar rumah. Ada 3 perilaku yang dapat berkontribusi atau berpotensi risiko penularan dan penyebaran virus COVID19 yaitu: (1) $89 \%$ responden menyentuh benda/uang yang disentuh juga oleh orang lain; (2) sering bepergian $86,3 \%$; dan (3) $46,3 \%$ responden berjabatan tangan dengan orang lain.

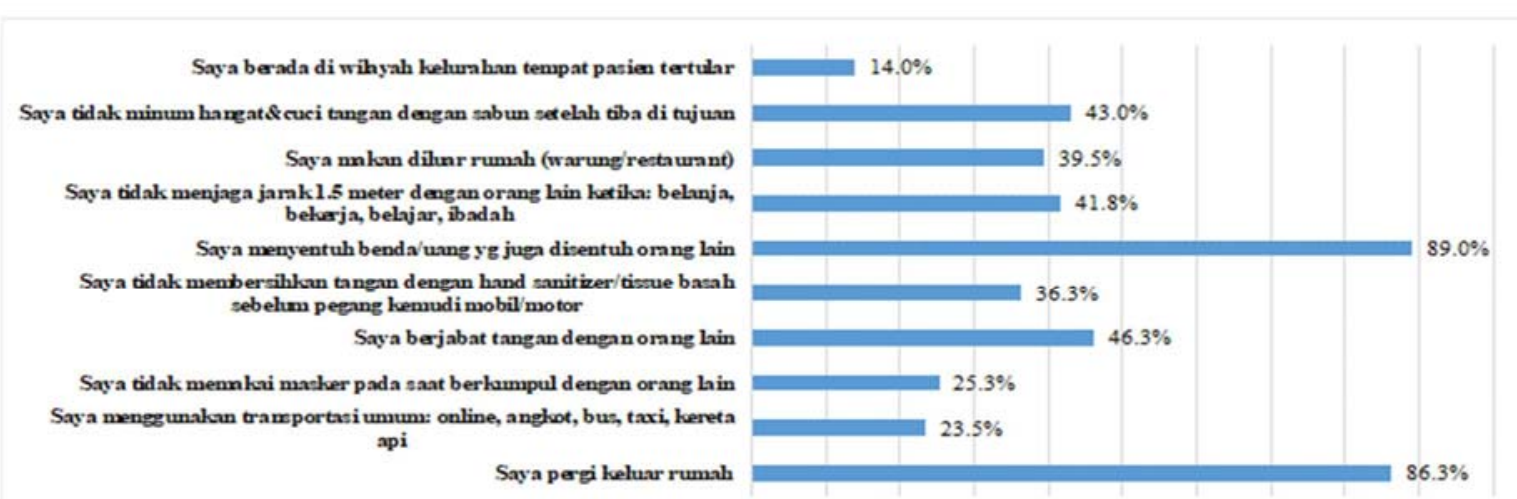

$0.0 \% \quad 10.0 \% \quad 20.0 \% \quad 30.0 \% \quad 40.0 \% \quad 50.0 \% \quad 60.0 \% \quad 70.0 \% \quad 50.0 \% \quad 90.0 \% 100.0 \%$

Gambar 13. Perilaku responden terkait risiko tertular di luar rumah 


\section{Pola Perilaku Berdasarkan Risiko Tertular di Dalam Rumah}

Potensi tertular di dalam rumah terjadi karena dimungkinkan adanya virus yang terbawa masuk ke dalam lingkungan rumah. Hal ini berhubungan dengan pola perilaku berdasar risiko tertular di luar rumah. Kontribusi utama penyebabnya (Gambar 14) adalah: (1) 55,5\% responden tidak menyediakan hand sanitizer di rumahnya; (2) $51 \%$ responden tidak segera merendam pakaian yang dipakai keluar rumah; (3) $49 \%$ responden tidak segera mandi setelah keluar rumah.

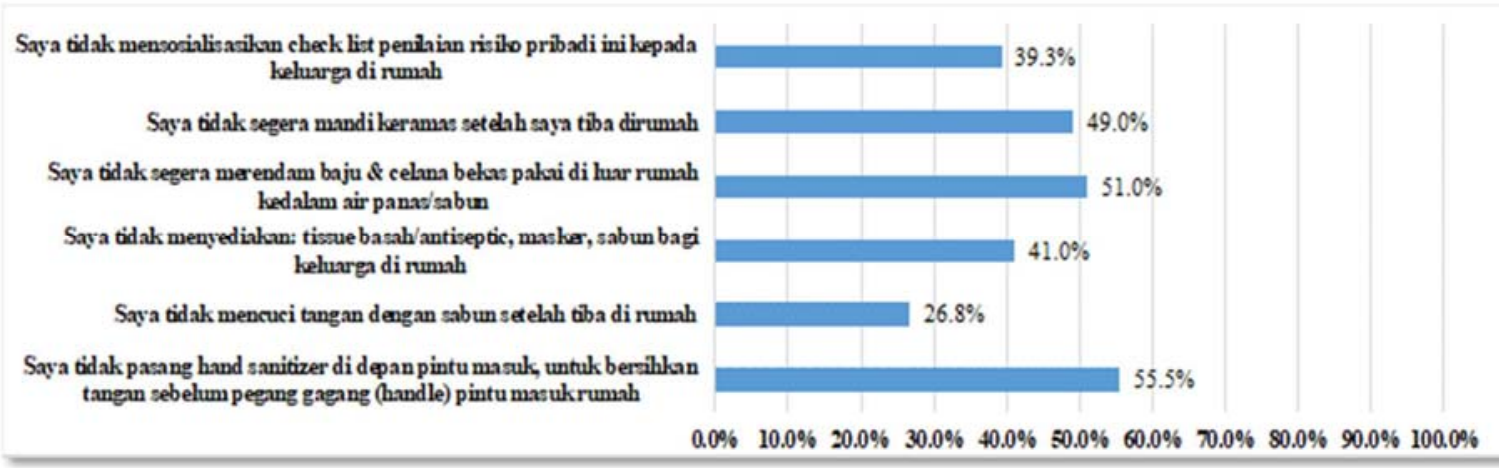

Gambar 14. Perilaku responden terkait risiko tertular di dalam rumah

\section{Pola Perilaku Berdasarkan Daya Tahan Tubuh atau Imunitas}

Faktor pendukung selain perilaku yang menyebabkan risiko tertular baik di luar maupun di dalam rumah adalah tingkat imunitas atau daya tahan tubuh. Beberapa hal yang terkait dengan imunitas (Gambar 15) adalah : (1) $46,8 \%$ responden jarang minum vitamin $C$ dan E serta kurang tidur; (2) $41,5 \%$ responden kurang olah raga dan jalan kaki minimal 20 menit; (3) 29\% responden tidak terkena matahari minimal 15 menit dalam sehari.

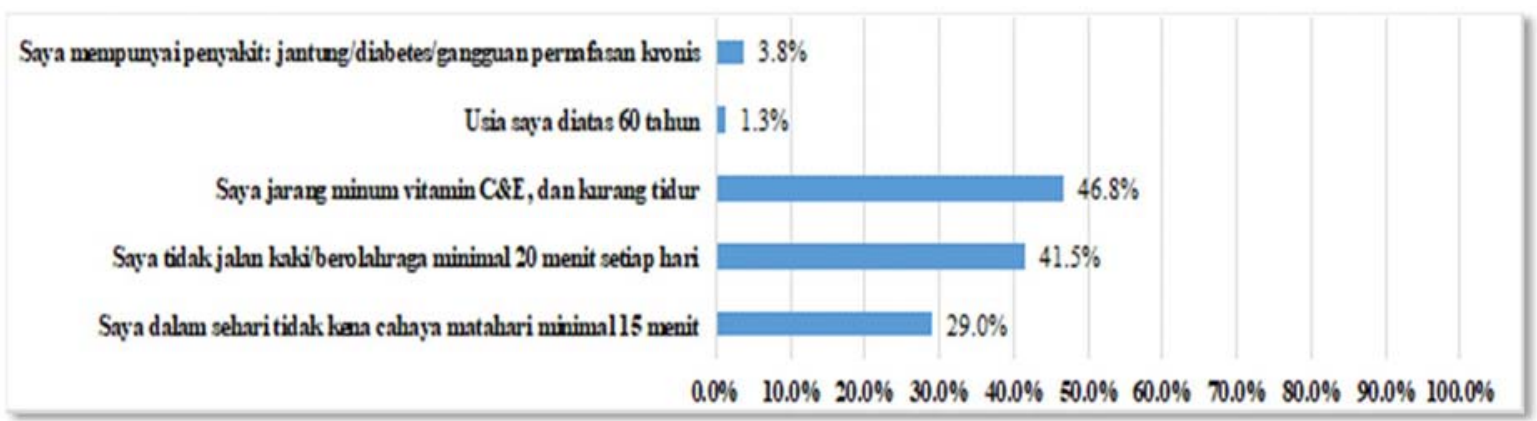

Gambar 15. Perilaku responden terkait imunitas atau daya tahan tubuh

\section{SIMPULAN DAN SARAN}

\section{Simpulan}

Penerapan aturan protokol kesehatan dalam tatanan kehidupan New Normal masyarakat dalam kondisi pandemi COVID-19 merupakan hal yang rasional yang harus dilakukan. Hal ini bertujuan untuk 
ABDIMAS: Jurnal Pengabdian Masyarakat Universitas Merdeka Malang

Volume 5, No 3, November 2020: 209-219

mencegah penularan dan penyebaran virus COVID-19. Upaya edukasi, sosialisasi, dan peningkatan kesadaran masyarakat secara berkelanjutan perlu dilakukan karena bencana ini telah menjadi sebuah pandemi. Berdasarkan hasil kegiatan pengabdian masyarakat ini dapat disimpulkan bahwa gambaran secara umum masih adanya potensi risiko sedang di masyarakat. Hal ini terkait dengan beberapa pola perilaku yang perlu diubah untuk mengurangi atau bahkan untuk mencegah penularan dan penyebaran virus COVID-19. Perubahan perilaku ini harus menjadi gerakan massal atau menjadi sebuah budaya dalam pola kehidupan New Normal.

\section{Saran}

Untuk memperoleh pemetaan kondisi masyarakat yang lebih spesifik perlu penetapan responden di wilayah tertentu terkait kebijakan yang akan diambil di wilayah tersebut. Perlu data spesifik responden terkait NIK dalam aplikasi InaRISK untuk menghindari pengulangan data responden. Aplikasi ini dapat dikolaborasikan dengan program-program lain terkait penanggulangan pandemi COVID-19 seperti program Kampung Tangguh.

\section{Daftar Pustaka}

Audry, C. L., Putri, M. R., Hilmi, Z. M. J., \& Firmadani, F. (2020). Edukasi pencegahan COVID-19 melalui media sosial. ABDIPRAJA (Jurnal Pengabdian kepada Masyarakat), 1(1), 130-139. https://doi.org/10.31002/abdipraja.v1i1.3145

Berawi, M. A. (2020). Empowering healthcare, economic, and social resilience during global pandemic COVID-19. International Journal of Technology, 11(3), 436-439.

https://doi.org/10.14716/ijtech.v11i3.4200

BNPB. (2020). http://inarisk.bnpb.go.id/panduan_singkat_ina.pdf. Diakses 11 September 2020

Irawan, D., Triana, N., Suwarni, L., \& Selviana, S. (2020). Edukasi protokol kesehatan dan strategi pemasaran online melalui program kemitraan masyarakat di era pandemi COVID-19. Jurnal Masyarakat Mandiri, 4(4), 655-662.

KMK No. HK.01.07-MENKES-413-2020. Pedoman Pencegahan dan Pengendalian COVID-19. https:// covid19.go.id/storage/app/media/Regulasi/KMK\%20No.\%20HK.01.07-MENKES-4132020\%20ttg\%20Pedoman\%20Pencegahan\%20dan\%20Pengendalian\%20COVID-19.pdf (diakses 11 September 2020)

Majid, N. (2020). Sosialisasi peran ibu rumah tangga sebagai pondasi ketahanan bangsa di tengah COVID-19 pada ibu PKK Desa Badak Baru Kabupaten Kutai Kartanegara. Jurnal Pengabdian Masyarakat (JPM-IKP), 3(2), 76-82. https://doi.org/10.31326/jmp-ikp.v3i2.697

Prayitno, S. A., Pribadi, H. P., \& Ifadah, R. A. (2020). Peran serta dalam melaksanakan protokol pencegahan penyebaran Corona Virus Disease (COVID-19) pada masyarakat. DedikasiMU(Journal of Community Service), 2(3), 504-510. https://doi.org/10.30587/dedikasimu.v2i3.1657

Sampurno, M. B. T., Kusumandyoko, T. C., \& Islam, M. A. (2020). Budaya media sosial, edukasi masyarakat, dan pandemi COVID-19. SALAM: Jurnal Sosial dan Budaya Syar-I, 7(5), 529-542. https://doi.org/10.15408/sjsbs.v7i5.15210 
Sosialisasi dan Edukasi Penilaian Mandiri terhadap Risiko Penularan COVID-19 melalui InaRISK Personal Sufiyanto Sufiyanto, Sari Yuniarti, Djoko Andrijono

Satria, B. A., Hasanah, N. H., \& Rudiansyah, R. (2020). Penyuluhan adaptasi tatanan kebiasaan baru desa tangguh COVID-19. ANOA, 1(3), 107-122. http://dx.doi.org/10.1234/anoa.v1i3.13242

Yunus, N. R., \& Rezki, A. (2020). Kebijakan pemberlakuan lock down sebagai antisipasi penyebaran Corona Virus Covid-19. SALAM: Jurnal Sosial \& Budaya Syar-i, 7(3), 227-238.

https://doi.org/10.15408/sjsbs.v7i3.15083

WHO. (2020). Pertimbangan penyesuaian langkah-langkah kesehatan masyarakat dan sosial dalam konteks COVID-19. https://www.who.int/docs/default-source/searo/indonesia/covid19/who2019-ncov-adjusting-ph-measures-2020-1-eng-indonesian.pdf?sfvrsn=63d5d4fe_2. Diakses 11 September 2020

Zahrotunnimah, Z. (2020). Langkah taktis pemerintah daerah dalam pencegahan penyebaran Virus Corona COVID-19 di Indonesia. SALAM: Jurnal Sosial dan Budaya Syar-i, 7(3), 247-260.

https://doi.org/10.15408/sjsbs.v7i3.15103 